\title{
Polymorphism and Comparative Expression Analysis of THRSP Gene in Fat-Tailed and Thin-Tailed Sheep Breeds
}

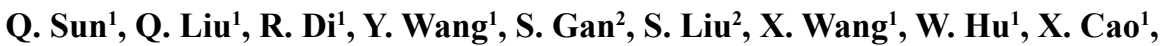 \\ Zh. Pan ${ }^{1}$, X. Guo ${ }^{1}$, Y. Yang ${ }^{3}$, H.E. Rushdi ${ }^{4 *}$ and M. Chu ${ }^{1 *}$ \\ ${ }^{1}$ Key Laboratory of Animal Genetics and Breeding and Reproduction of Ministry \\ of Agriculture and Rural Affairs, Institute of Animal Science, Chinese Academy of \\ Agricultural Sciences, Beijing 100193, PR China \\ ${ }^{2}$ State Key Laboratory of Sheep Genetic Improvement and Healthy Production, Xinjiang \\ Academy of Agricultural and Reclamation Sciences, Shihezi, 832000, PR China \\ ${ }^{3}$ Beijing General Station of Animal Husbandry, Beijing 100101, PR China \\ ${ }^{4}$ Department of Animal Production, Faculty of Agriculture, Cairo University, Giza, \\ 12613, Egypt.
}

Q. Sun and Q. Liu contributed equally to this study.

Article Information
Received 12 August 2019
Revised 02 September 2019
Accepted 14 September 2019
Available online 12 February 2021
Authors' Contribution
QL designed the study. QS and QL
performed the experiments, analyzed
data, and wrote the first draft. RD,
YW, SG and SL supported the
sampling and genotyping of animals.
XW, WH, XC and ZP provided
analysis tools. XG and YY provided
support in statistical analysis of data.
HER and MC critically reviewed and
revised the manuscript.
Key words
Altay sheep, Fat tail, THRSP gene,
SNP

\section{A B S T R A C T}

Sheep is a significant agricultural animal and food source for people worldwide. The fat tail/rump is considered as an adaptive selection under harsh challenges which serves as a fat store for the animal. Thyroid hormone responsive (THRSP) is a crucial protein for cellular de novo lipogenesis. THRSP gene encodes a nuclear protein which regulates fatty acid synthesis in lipogenic tissues. Identification of single nucleotide polymorphisms (SNPs) of sheep THRSP gene and their association with fat deposition were investigated using Altay and White Suffolk sheep. In addition, the messenger RNA expression profiling of THRSP in fat-tailed and thin-tailed breeds was compared among 8 different tissues. Four SNPs have been detected in position g. $205 \mathrm{~A}>\mathrm{C}$, c. $52 \mathrm{C}>\mathrm{T}$, c. $364 \mathrm{~A}>\mathrm{T}$ and c. $1031 \mathrm{C}>\mathrm{T}$ of THRSP gene. Genotyping method was used to analyze genotypes among Altay sheep (fat-rumped breed) and White Suffolk (thintailed breed) by Sequenom MassArray. In the c.1031C $>\mathrm{T}$ locus, the frequency of $\mathrm{T}$ allele of fat-tail breed was significantly $(\mathrm{p}<0.001)$ higher than that of the thin-tailed breed using $\mathrm{F}$ test, which suggest that this locus may be associated with fat deposition in fat-tail breed. Gene expression levels in both subcutaneous adipose and tail fat tissues were significantly $(\mathrm{p}<0.01)$ higher than the other tissues analyzed. Levels of THRSP expression in liver, subcutaneous adipose and tail fat tissues in Tan sheep (thin-tailed breed) were significantly $(\mathrm{p}<0.01)$ higher than that in Altay sheep (fat-tailed breed). The results obtained might expand our understanding of the important regulating role of THRSP gene in lipogenesis in fat-tailed sheep breed.

\section{INTRODUCTION}

$\mathrm{S}^{\mathrm{h}}$ heep (Ovis aries) was probably the first domesticated animal in the Fertile Crescent region on the discovery of the archaeological evidence (Mason, 1984). There is a spectrum of phenotypically diverse populations of sheep worldwide due to their manageable size, early maturity, diverse products, to poor nutritional diets, tolerance to extreme climatic conditions and economic performance under harsh environments (Kijas et al., 2009). According to the tail types, sheep can be categorized into five groups,

\footnotetext{
* Corresponding author: hosamrushdi@agr.cu.edu.eg; mxchu@263.net 0030-9923/2021/0002-0545 \$ 9.00/0

Copyright 2021 Zoological Society of Pakistan
}

including fat rump, short- and long-thin tail, as well as short- and long-fat tail breeds (Zhang et al., 2019).

China has the most diverse sheep breeds compared to other countries. Altay sheep is a local breed native to Xinjiang (China), famous for tasty, high meat production and strong adaptability in rigid environments. This breed is one of the most important sheep in Xinjiang which is a kind of typical fat-rumped breed (China National Commission of Animal Genetic Resources, 2011). The Altay sheep has a large rump composed entirely of white adipose tissue which accounts for about $18 \%$ of the carcass content. The fat tail/rump is considered as a selection of evolution which serves as a fat store for the animal under harsh environment. However, more energy is needed for fat than for protein (lean meat) deposition. Nowadays, reduction in fat tail size is often desirable for both sheep 
stakeholders and mutton consumers. Consequently, the advantages of large fat tail/rump have begun to fade due to changing consumer preferences (Ahbara et al., 2018).

Several studies have been carried out to evaluate growth performance and carcass characteristics using fat-tailed and lean-tailed sheep breeds (Khaldari et al., 2008; Pourlis, 2011). Advances achieved in molecular biology and genomics have made possible the study of genetic background of economically important traits. In this respect, the next-generation sequencing platforms have been employed to explore candidate genes / genomic regions linked to fat deposition in thin- and fat-tailed sheep breeds. A genome-wide scan was performed based on OvineSNP50K Beadchip in Iranian thin- and fat-tailed breeds, and two of identified regions were associated with an increase of homozygosity in the fat-tailed breeds (Moradi et al., 2012). De novo transcriptome sequencing was used to compare sheep adipose tissue transcriptome profiles between fat-tailed and short-tailed breeds. Approximately 646 differentially expressed genes and functional pathways were identified (Wang et al., 2014). Up to date; however, the genes affecting fat deposition in fat tails of domesticated sheep are still scarce.

Thyroid hormone responsive (THRSP or Spot14) gene encodes a nuclear protein which regulates fatty acid synthesis in lipogenic tissue (Donnelly et al., 2008). It is induced by thyroid hormone, carbohydrate intake, adipose tissue differentiation, and lactation. Expression profiling of THRSP gene goes in line with fatty acid synthase in adipose, liver, and mammary tissue in bovine and murine species (Zeng et al., 2018). Spot14 protein is expressed primarily in tissues which synthesize fatty acids. The expression levels of THRSP mRNA in white adipose tissue, brown adipose tissue and liver are elevated when de novo fatty acid synthesis is induced by dietary and hormonal stimuli (Chou et al., 2007).

To the best of our knowledge, no associations between SNPs within THRSP gene and fat metabolism in fat-tailed and thin-tailed sheep breeds have been reported. Therefore, the present study was undertaken to identify SNP variants in THRSP gene and to evaluate their potential association with fat deposition in the tail of Altay and White Suffolk sheep breeds. Also, THRSP gene expression profiles was targeted in adipose tissues of fat-tailed and thin-tailed sheep breeds.

\section{MATERIALS AND METHODS}

\section{Sampling and DNA extraction}

All procedures involving animals were approved by the Animal Care and Use Committee at the respective institutions where the present study was conducted.
Also, such procedures involving animals were officially authorized later by the Chinese Ministry of Agriculture.

For SNP analysis study, 200 ewes of two different breeds reared in China were selected. Sampling process included 100 Altay sheep belonging to Fuyun Breeding Farm (Fuyun County, Xinjiang Uygur Autonomous Region, P.R. China) and 100 White Suffolk from Beijing Aoxin Stud Farm Co. Ltd. (Beijing, P.R. China). All the sampled individuals were in a good state of health and nutrition. Ear tissue taken from each Altay sheep was immersed in $70 \%$ ethanol under $4^{\circ} \mathrm{C}$ and stored at $-20^{\circ} \mathrm{C}$ pending for DNA isolation. On the other hand, blood samples from the jugular vein of White Suffolk were collected in tubes containing acid citrate dextrose as an anticoagulant. Genomic DNA was extracted from ear tissue and whole blood by the phenol-chloroform method depending on the breed, and then dissolved in TE buffer composed of $10 \mathrm{mmol} / \mathrm{l}$ Tris-HCl $(\mathrm{pH} 8.0), 1 \mathrm{mmol} / \mathrm{l}$ EDTA ( $\mathrm{pH} 8.0$ ), and then kept at $-20^{\circ} \mathrm{C}$.

For gene expression analysis study, three animals of Altay sheep reared at the animal housing facilities of Xinjiang Academy of Agriculture and Reclamation Science, Shihezi, China as well as other three individuals of Tan sheep owned by Breed Conservation Farm in the Ningxia Hui Autonomous Region, China were subjected to this experiment. The dorsal subcutaneous adipose tissue samples taken from each animal were frozen in liquid nitrogen and stored at $-80^{\circ} \mathrm{C}$ till RNA isolation.

\section{Primers and PCR amplification}

Five pairs of primers (P1, P2, P3, P4, P5) were designed according to the mRNA sequences of sheep THRSP gene (GenBank Accession Number: XM_004019431) and DNA sequence of 5'UTR of goat THRSP gene (GenBank Accession Number: JN684754.1 or JN6847541). Molecular data corresponding to the primers amplified in the current study are given in Table I. The DNA fragments of the studied gene were amplified using Polymerase Chain Reaction (PCR) technique. PCRs were carried out in 25 $\mu \mathrm{l}$ volume containing approximately $1.0 \mu \mathrm{l}$ of $10 \mu \mathrm{mol} / 1$ each primer, $2.5 \mu \mathrm{l}$ of $10 \times \mathrm{PCR}$ buffer $(50 \mathrm{mmol} / \mathrm{l} \mathrm{KCl}$, $10 \mathrm{mmol} / \mathrm{l}$ Tris-HCl (pH 8.0), $0.1 \%$ Triton X-100), 1.0$1.8 \mu \mathrm{l}$ of $25 \mathrm{mmol} / 1 \mathrm{MgCl}_{2}, 2.5 \mu \mathrm{l}$ of $2.5 \mathrm{mmol} / \mathrm{l}$ each $\mathrm{dNTP}, 3.0 \mu \mathrm{l}$ of $50 \mathrm{ng} / \mu \mathrm{l}$ ovine genomic DNA, $1.0 \mu \mathrm{l}$ of $2.5 \mathrm{U} / \mu \mathrm{Taq}$ DNA polymerase (Promega, Madison, WI, USA), and the rest was $\mathrm{ddH}_{2} \mathrm{O}$. PCR conditions were as follows: initial denaturation at $95^{\circ} \mathrm{C}$ for $5 \mathrm{~min}$, followed by 35 cycles of denaturation at $95{ }^{\circ} \mathrm{C}$ for 30 $\mathrm{s}$, annealing for $30 \mathrm{~s}$, extension at $72{ }^{\circ} \mathrm{C}$ for $45 \mathrm{~s}$, with a final extension at $72{ }^{\circ} \mathrm{C}$ for $10 \mathrm{~min}$ on Mastercycler 5333 (Eppendorf AG, Hamburg, Germany). 
Table I. Primers used for THRSP gene analysis.

\begin{tabular}{|c|c|c|c|c|c|c|}
\hline & $\begin{array}{l}\text { Primer } \\
\text { name }\end{array}$ & Primer sequence $\left(5^{\prime} \rightarrow 3^{\prime}\right)$ & $\begin{array}{l}\text { Amplified } \\
\text { regions }\end{array}$ & $\begin{array}{l}\text { Product } \\
\text { size(bp) }\end{array}$ & $\begin{array}{l}\text { Annealing tem- } \\
\text { perature }\left({ }^{\circ} \mathrm{C}\right)\end{array}$ & $\begin{array}{l}\text { Reference } \\
\text { sequences (NCBI) }\end{array}$ \\
\hline P1 & THRSP 1 & $\begin{array}{l}\text { F: GGGTCAATGGTGAAGACGAAGCT } \\
\text { R: GCCAAGTACCGGTCCATGACG }\end{array}$ & 5'UTR & $1 \mathrm{k}$ & 58 & KT266274 \\
\hline P2 & THRSP2 & $\begin{array}{l}\text { F: CTCTAAATGGCTCTGCAAGCTGATG } \\
\text { R: TAGCCCTCTTTTAGGCCAATCCTAG }\end{array}$ & 5'UTR & 200 & 55 & KT266274 \\
\hline P3 & THRSP3 & $\begin{array}{l}\text { F: TGACCAAGCGCTACCCTAAG } \\
\text { R: CTCCTCGGCTTTCAGGGTAA }\end{array}$ & Exon 1 & 400 & 57 & XM_004019431 \\
\hline P4 & THRSP4 & $\begin{array}{l}\text { F: GTGATGATCCCCAGCCTTCT } \\
\text { R: TACCCTCTCTTCCTCAGCCT }\end{array}$ & Exon 2 & 230 & 53 & XM_004019431 \\
\hline P5 & THRSP5 & $\begin{array}{l}\text { F: ACTCCACATGATAGAAGGCAGT } \\
\text { R: AGTCCGAAAACTTGTCCAAAATT }\end{array}$ & 3'UTR & 802 & 57 & XM_004019431 \\
\hline & THRSP & $\begin{array}{l}\text { F: GGAGAGATGGAAGAGGCTGAG } \\
\text { R: CTCCTCGGCTTTCAGGGTAA }\end{array}$ & Real-time PCR & 123 & 58 & XM_004019431 \\
\hline & GAPDH & $\begin{array}{l}\text { F:ATGCCTCCTGCACCACCA } \\
\text { R: AGTCCCTCCACGATGCCAA }\end{array}$ & Real-time PCR & 76 & 58 & NM_001190390 \\
\hline
\end{tabular}

Table II. SNPs detected in ovine THRSP.

\begin{tabular}{|c|c|c|c|c|}
\hline Position & & & HRSP & \\
\hline Nucleotide position & g. $205 \mathrm{~A}>C$ & c. $52 \mathrm{C}>\mathrm{T}$ & c. $364 \mathrm{~A}>\mathrm{T}$ & c. $1031 \mathrm{C}>\mathrm{T}$ \\
\hline Amino acid position & / & 10 & 114 & I \\
\hline Codon in Altay & / & C/TTG & T/ATG & I \\
\hline Codon in Suffolk & / & $\mathrm{C} / \mathrm{TTG}$ & T/ATG & I \\
\hline Amino acid in Altay & / & $\mathrm{L}$ & $\mathrm{L} / \mathrm{M}$ & I \\
\hline Amino acid in Suffolk & / & $\mathrm{L}$ & $\mathrm{L} / \mathrm{M}$ & I \\
\hline SNP type & S & NS & NS & $\mathbf{S}$ \\
\hline
\end{tabular}

$\mathrm{NS}=$ Non-synonymous; $\mathrm{S}=$ Synonymous

The PCR products were separated by electrophoresis on $2 \%$ agarose gels (Promega, Madison, WI, USA) in parallel with DNA Marker I (Tiangen, Beijing, P.R. China). Gels were visualized using a $1.5 \%$ agarose gel containing ethidium bromide, photographed, and analyzed using an AlphaImager ${ }^{\mathrm{TM}} 2200$ and 1220 Documentation and Analysis Systems (Alpha Innotech Corporation, San Leandro, CA, USA).

\section{SNP analysis}

Ten individuals from each sheep breed were selected randomly. Genomic DNA from Altay sheep and White Suffolk sheep was used as a template to be amplified with the five pairs of primers (P1-P5). Sequences were aligned to search for the base pair variations. PCR products were separated on $2 \%$ agarose gels and recovered using Geneclean II kit (Promega, Madison, WI, USA). Each DNA fragment was sequenced in both directions using an automatic ABI 3730 sequencer (Perkin Elmer Applied Biosystems, Foster City, CA, USA) by Sino Geno Max Co. Ltd. (Beijing, China). Sequence analysis and amino acid determination were performed by DNAMAN version 9.0 and DNAstar lasergene 7.1.

\section{Genotyping}

Ten out of 200 animals from Altay and White Suffolk sheep were selected for genotyping. Genotyping was performed using primer extension chemistry and mass spectrometric analysis (iPlex assay, Sequenom, San Diego, CA) on the Sequenom MassArray according to the manufacturer's instructions (http://www.sequenom.com). Only those samples with a $>95 \%$ success rate and only those SNPs with a genotype success rate of $>95 \%$ were included in the subsequent analysis.

Allele and genotype frequencies were estimated by direct counting. Statistical analyses were performed by 
SAS program (Ver 8.1) (SAS Institute Inc., Cary, NC, USA). Differences between the two groups of samples were accessed using $t$-test assuming unequal variances. $P$ values less than 0.05 were considered to be significant. Chi-square test was applied to analyze the statistical significance of genotypic distributions of the two sheep breeds under study.

\section{Total RNA extraction and cDNA preparation}

Total RNA was prepared from each frozen sample and purified by using the QIAZOL Lysis Reagent (RNeasy Lipid Tissue) according to the manufacturer's instructions (Qiagen, Valenci, CA, USA). About $1 \mu \mathrm{g}$ RNA was reverse transcribed into single-strand cDNA using oligo(dT) ${ }_{18}$-mer primers and M-MLV Reverse Transcriptase (Invitrogen, Karlsruhe, Germany).

\section{Quantitative real-time PCR}

Reverse transcription polymerase chain reaction (RTPCR) was performed on a fluorescence thermal cycler (ABI PRISM ${ }^{\circledR}$ 7500HT Sequence Detection System, Applied Biosystems). A standard two-step procedure was applied. RNAs were reverse transcribed into single strand cDNAs as described above. PCR was performed in 15$\mu \mathrm{L}$ reaction mixtures consisting of $\mathrm{cDNA}, 0.5 \mu \mathrm{M}$ specific primer sets for each target gene, and SYBR Green PCR Master Mix (Applied Biosystems, UK). RT-PCR were cycled with the following conditions: $50^{\circ} \mathrm{C}$ for $2 \mathrm{~min}, 95^{\circ} \mathrm{C}$ for $10 \mathrm{~min}$, followed by 40 repetitive cycles of $95^{\circ} \mathrm{C}$ for $15 \mathrm{sec}$ and $60^{\circ} \mathrm{C}$ for $1 \mathrm{~min}$. Glyceraldehyde 3-phosphate dehydrogenase (GAPDH) gene was used as internal control to normalize for initial RNA input. The primers used for PCR are listed in Table I. The specificity and quantity of each RT-PCR product were checked by melting curve analysis according to the following program: $95^{\circ} \mathrm{C}$ for 15 $\mathrm{sec}, 60^{\circ} \mathrm{C}$ for $15 \mathrm{sec}, 95^{\circ} \mathrm{C}$ for $15 \mathrm{sec}$. Relative expression of each gene was calculated according to the $2^{-\Delta \Delta \mathrm{Ct}}$ method. Differential expression of THRSP was analyzed using one way ANOVA at $p<0.05$. Each PCR reaction was run in triple for each independent sample.

\section{RESULTS}

\section{Polymorphism identification and detection}

Genomic DNA of the two sheep breeds (Altay and White Suffolk) was successfully amplified using primers P1-P5 for THRSP gene. A total of 10 PCR products amplified by each primer pair was selected randomly and subsequently cloned for sequencing. Molecular information about the SNPs detected in ovine THRSP gene is summarized in Table II. PCR products amplified by primers P1, P3, P4 and P5 displayed polymorphisms which had four base pair changes (g. 205A>C, GenBank Accession Number: KT266274; c.52C $>$ T, c. $364 \mathrm{~A}>\mathrm{T}$ and $\quad$ c. $1031 \mathrm{C}>\mathrm{T}$, GenBank Accession Number: XM_004019431). The g. 205A $>C$ and c.1031C $>$ T are located in 5' and 3'UTR, respectively. Non-synonymous c. $52 \mathrm{C}>\mathrm{T}$ SNP and non-synonymous c.364A $>\mathrm{T}$ SNP both are located in exon 1.

Table III. Allele and genotype frequencies of THRSP gene in Altay and Suffolk breeds.

\begin{tabular}{|c|c|c|}
\hline Genotype & Altay & Suffolk \\
\hline THRSP g. 205A >C & $\mathrm{n}=97$ & $\mathrm{n}=96$ \\
\hline \multirow[t]{3}{*}{ Genotype frequency } & AA $0.36(35)$ & AA $0.35(34)$ \\
\hline & AC $0.51(49)$ & $\mathrm{AC} 0.47(45)$ \\
\hline & CC 0.13(13) & CC 0.18(17) \\
\hline \multirow[t]{2}{*}{ Allele frequency } & A 0.613 & A 0.589 \\
\hline & C 0.387 & C 0.411 \\
\hline $\mathrm{H}-\mathrm{W}$ test $\chi^{2}$ & 0.411 & 0.0993 \\
\hline $\mathrm{P}$ & 0.521 & 0.753 \\
\hline THRSP c. $52 \mathrm{C}>\mathrm{T}$ & $\mathrm{n}=100$ & $\mathrm{n}=98$ \\
\hline \multirow[t]{2}{*}{ Genotype frequency } & CC $0.95(95)$ & CC $0.969(95)$ \\
\hline & СТ $0.05(5)$ & СТ 0.031 (3) \\
\hline \multirow[t]{2}{*}{ Allele frequency } & C 0.975 & C 0.985 \\
\hline & Т 0.025 & Т 0.015 \\
\hline $\mathrm{H}-\mathrm{W}$ test $\chi^{2}$ & 0.0658 & 0.0237 \\
\hline $\mathrm{P}$ & 0.798 & 0.878 \\
\hline THRSP c. $364 \mathrm{~A}>\mathrm{T}$ & $\mathrm{n}=100$ & $\mathrm{n}=97$ \\
\hline \multirow[t]{2}{*}{ Genotype frequency } & AT $0.06(6)$ & AT $0.041(4)$ \\
\hline & TT 0.94(94) & TT 0.959(93) \\
\hline \multirow[t]{2}{*}{ Allele frequency } & А 0.03 & A 0.021 \\
\hline & Т 0.97 & Т 0.979 \\
\hline $\mathrm{H}-\mathrm{W}$ test $\chi^{2}$ & 0.0957 & 0.0429 \\
\hline $\mathrm{P}$ & 0.757 & 0.836 \\
\hline THRSP c. $1031 \mathrm{C}>\mathrm{T}$ & $\mathrm{n}=98$ & $\mathrm{n}=98$ \\
\hline \multirow[t]{3}{*}{ Genotype frequency } & CC $0.510(50)$ & CC 0.867 (85) \\
\hline & СТ $0.388(38)$ & СТ $0.102(10)$ \\
\hline & ТT $0.102(10)$ & TT 0.031 (3) \\
\hline \multirow[t]{2}{*}{ Allele frequency } & C 0.704 & C 0.918 \\
\hline & Т 0.296 & Т 0.082 \\
\hline $\mathrm{H}-\mathrm{W}$ test $\chi^{2}$ & 0.473 & 10.0 \\
\hline $\mathrm{P}$ & 0.492 & 0.00157 \\
\hline
\end{tabular}

These four mutations were detected by Sequenom Mass Array in the two sheep breeds with different tail 
types (Altay as a fat-tailed breed and Suffolk as a thintailed breed). The total detection rate was $97.7 \%$. As demonstrated in Figure 1 and Table III, A to $\mathrm{C}$ transversion at site g.205A $>$ C expressed three genotypes: $\mathrm{AA}, \mathrm{AC}$ and CC. While $\mathrm{C}$ to $\mathrm{T}$ transversion at site $\mathrm{c} .52 \mathrm{C}>\mathrm{T}$ revealed only two genotypes: CC and CT. Similarly, A to T transition at site c.364A $>$ T expressed two genotypes: AT and TT. On the other hand, $\mathrm{C}$ to $\mathrm{T}$ transversion at site $\mathrm{c} .1031 \mathrm{C}>\mathrm{T}$ shown three genotypes: CC, CT and TT.
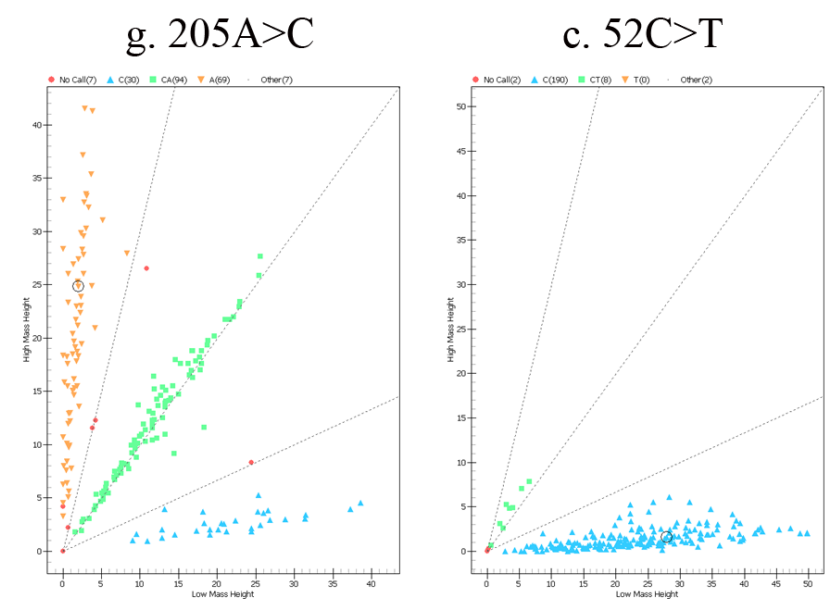

c. $364 \mathrm{~A}>\mathrm{T}$

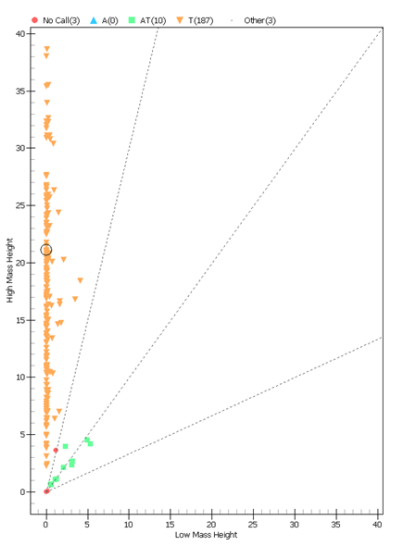

c. $1031 \mathrm{C}>\mathrm{T}$

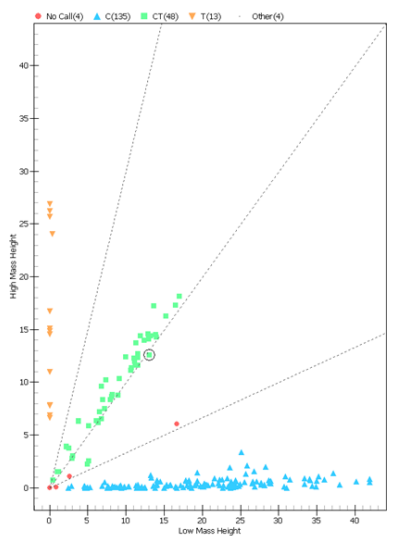

Fig. 1. The results of sequenom massarray at (g. 205A $>$ C), (c. $52 \mathrm{C}>\mathrm{T}),($ c. $364 \mathrm{~A}>\mathrm{T}),($ c. $1031 \mathrm{C}>\mathrm{T})$ in sheep THRSP gene.

Allele and genotype frequencies of sheep THRSP gene

Allelic and genotypic frequencies of THRSP gene in Altay and White Suffolk breeds were calculated (Table III). F test was applied to determine the statistical significance of allele frequencies between the two sheep breeds. As shown in Table III, allele A is the dominant allele in both breeds at the g. $205 \mathrm{~A}>\mathrm{C}$ locus. At the locus c. $52 \mathrm{C}>\mathrm{T}$, allele $\mathrm{C}$ is largely dominant over allele $\mathrm{T}$ in the two studied breeds. However, no statistically significant difference is found between both alleles in each individual breed. In respect to locus c. $364 \mathrm{~A}>\mathrm{T}$, a pair of alleles is identified (A and $\mathrm{T}$ ), without significant difference between fat-tailed breed and thin-tailed breed at the respective locus located in exon 1 of THRSP gene. For the c.1031C $>\mathrm{T}$ locus, allele $\mathrm{C}$ is the most common in the two sheep breeds compared to allele T. The difference between both alleles is statistically significant only in the thin-tailed breed. White Suffolk is significantly deviated from Hardy-Weinberg equilibrium $(p<0.01)$. The frequency of $\mathrm{T}$ allele of fat-tailed breed is significantly $(p<0.001)$ higher than that of thin-tailed breed, indicating that the c. $1031 \mathrm{C}>\mathrm{T}$ locus may be associated with fat deposition in fat-tailed sheep breeds.

\section{Tissue distribution of THRSP $m R N A$}

The distribution of THRSP mRNA expression in eight tissues (heart, liver, spleen, lung, kidney, skeletal muscle, subcutaneous adipose and tail fat) was examined by RTPCR, using a pair of specific primers amplifying a 123-bp amplicon of this gene. The house-keeping gene GAPDH was used as an internal control for normalization (Fig. 2A). Interestingly, a relatively high level of expression of THRSP can be only detected in the subcutaneous adipose and tail fat tissue which were extremely higher than the corresponding expression in the other six tissues $(>1000$ fold, $\mathrm{p}<0.01)$. Higher mRNA levels were detected in the liver than in the spleen, lung, kidney and skeletal muscle, while there was almost no expression level shown in the heart of Altay sheep.

Table IV. Test of difference of the loci genotype distributions in Altay and Suffolk breeds.

\begin{tabular}{llll}
\hline Breeds & Suffolk & & \\
\hline \multirow{4}{*}{ Altay } & SNP locus & $\chi^{2}$ & $\mathrm{P}$ \\
& THRSP g. $205 \mathrm{~A}>\mathrm{C}$ & 0.713 & 0.7 \\
& THRSP c. $52 \mathrm{C}>\mathrm{T}$ & 0.48 & 0.488 \\
& THRSP c. $364 \mathrm{~A}>\mathrm{T}$ & 0.36 & 0.549 \\
& THRSP c. $1031 \mathrm{C}>\mathrm{T}$ & 29.177 & $4.62 \mathrm{E}-07$ \\
\hline
\end{tabular}

\section{Expression levels of THRSP in adipose-related tissues}

To further determine the differential expression between two breeds with different tail types, mRNA levels of THRSP in liver, subcutaneous adipose and tail fat tissues were determined based on RT-PCR in Altay and Tan sheep breeds. As shown in Figure 2B, the highest THRSP mRNA expression level is shown in the subcutaneous fat tissue, followed by tail fat and liver for the two studied breeds. Significantly $(p<0.01)$ higher 
THRSP expression levels are observed in Tan compared to Altay sheep for all examined tissues.
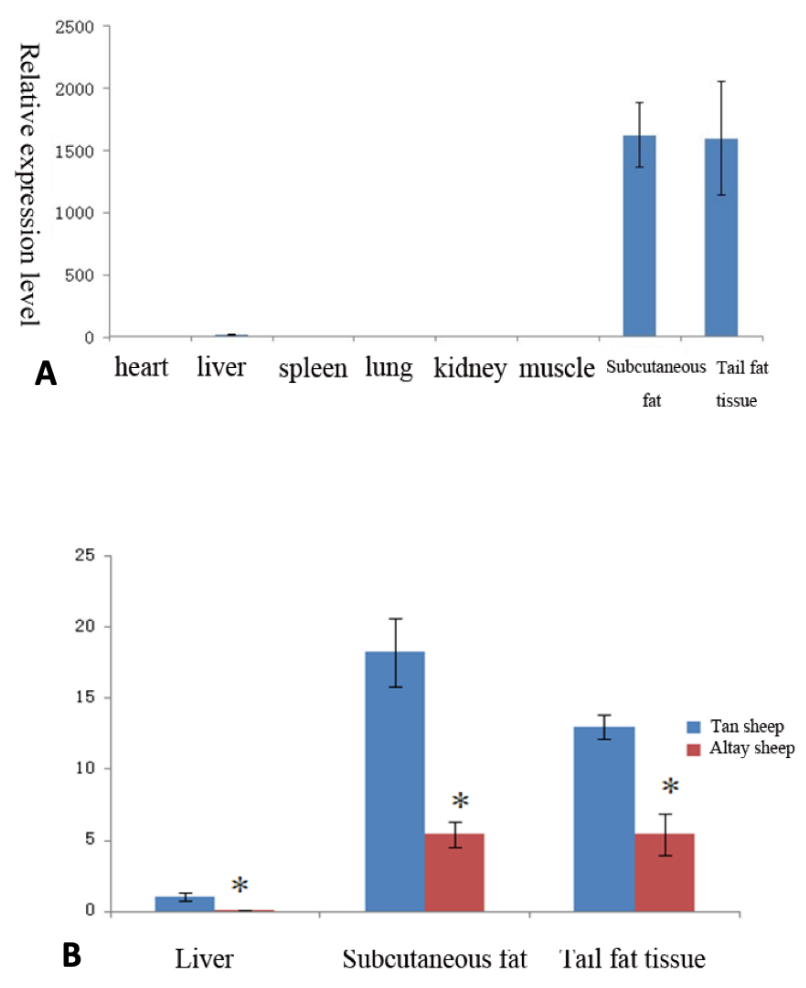

Fig. 2. Gene expression profiles of THRSP gene. (A) Expression levels of THRSP gene in heart, liver, spleen, lung, kidney, muscle, subcutaneous fat and tail fat tissue in Altay sheep (B) Expression levels of THRSP gene in liver, subcutaneous fat, tail fat tissue of Tan sheep and Altay sheep.

\section{DISCUSSION}

The fat-tailed sheep breeds are characterized by the distinctive large tails and hindquarters. Approximately $25 \%$ of the world sheep populations comprise fat-tailed breeds which are commonly found in the northern parts of Africa, the Middle East, Central Asia, and Western China (Pourlis, 2011). Altay sheep chosen for this study has a large rump composed entirely of white adipose tissue which is known for their ability to cope with harsh environmental conditions such as drought and famine in northern part of Xinjiang Uygur Autonomous Region. Due to improved forage availability, healthy issue and change in consumption patterns and trends, fat-tailed trait, fat tail trait is commercially undesirable now. Accordingly, today's sheep breeders are highly interested in finding useful molecular markers that can be incorporated into contemporary sheep breeding programs through marker- assisted selection (MAS) or genomic selection (GS). So, searching for gene variants affecting the phenotypic expression of fat-tailed trait in ovine species is becoming a hot topic in molecular genetics.

Biological processes such as lipogenesis and adipogenesis are governed by a vast number of enzymes which act together along with hormones and metabolites to regulate fat cell metabolism (Cornelius et al., 1994; Farmer, 2006). The main role of white adipose tissue is triacylglycerol (TAG) storage and fatty acid (FA) release. The direct action on adipose tissue should be to activate lipolytic enzymes and coordinate endocrine signals to initiate lipolysis. Adipocyte precursor differentiation is driven by a cascade of events regulated by transcription regulators and coactivators. This entire process is closely regulated at the transcriptional level (Rosen and MacDougald, 2006; Rosen and Spiegelman, 2000). Up to now, there is little published information related to fat tail syndrome especially for the Chinese local sheep breeds. Several candidate genes have been involved in association studies with fat deposition and lipid metabolism in domestic animals. One of these major genes is Peroxisome Proliferator Activated Receptor Gamma (PPARG), which is a protein coding gene. PPARG and its target genes are factors leading to greater intramuscular fat deposition in cattle (Moisa et al., 2014). Also, heart-type fatty acidbinding protein (H-FABP) plays role in fat deposition and the regulation of fatty acid metabolism in Lanzhou fat-tailed sheep (Bai et al., 2013). The mRNA abundance of G-protein coupled receptor 41 (GPR41), adiponectin receptors 1 and 2 (AdipoR1/2) and leptin is divergent in different fat depots from sheep (Lemor et al., 2010). There were novel associations of DGAT1 gene in which the C allele had a positive effect on fat-tail weight and backfat thickness in fat-tailed sheep (Mohammadi et al., 2013). THRSP was suggested as a transcription factor to regulate gene expression of rate-limiting enzymes in lipogenesis. Transcription is regulated via thyroid hormone and the SREBP-1c binding sites (Wu et al., 2013). THRSP null mouse weight gain is resultant from decreased fat accumulation and is associated with improvement in glucose tolerance (Anderson et al., 2009). In addition, the THRSP gene may contribute to fat accumulation in humans (Ortega et al., 2010). In parallel, THRSP has been studied in different farm animals species, THRSP gene expression is highly correlated with the intramuscular fat content of cattle (Wang et al., 2009). The mutations of THRSP gene had an important effect on body weight in the chicken (Cao et al., 2007). Three mutational sites, C-233T, G113A and A138G of THRSP were detected in Chinese indigenous goat breeds, and those polymorphisms may be associated with the ecological factors and affect the goat lipogenesis 
ability (Chen et al., 2012).

In the present study, four polymorphic sites (g.205A>C, GenBank Accession Number: KT266274; c. $52 \mathrm{C}>\mathrm{T}$, c. $364 \mathrm{~A}>\mathrm{T}$ and c. $1031 \mathrm{C}>\mathrm{T}$, GenBank Accession Number: XM_004019431) of sheep THRSP gene were detected. The g.205A $>\mathrm{C}$ and c.1031C $>\mathrm{T}$ located in 5, and 3'UTR, respectively. The variations identified in the coding region did not largely change the genotype frequencies between fat-tailed and thin-tailed breeds. T allele frequency of $\mathrm{c} .1031 \mathrm{C}>\mathrm{T}$ in fat tail breed was higher than that of the thin tail breed, which may indicate that this locus may be associated with fat deposition in fattail breed. It has been commonly recognized that SNPs which occur in the 3'UTR can affect gene regulation by interfering with posttranscriptional activity, such as protein binding, polyadenylation and miRNA binding (Sethupathy et al., 2007). A 3'UTR SNP in the sheep Gdf8 gene creates a new illegitimate miRNA target site, which leads to significant down-regulation of Gdf8 and contributes to muscular hypertrophy (Clop et al., 2006). The expression of human AGTR1 gene that contains one SNP in 3'UTR can be regulated by has-miR-155 to associate with hypertension in trisomy 21 (Sethupathy et al., 2007). It has been reported that THRSP can be targeted by miR3582 to affect the lactation in rat (Zhang et al., 2014). As the c.1031C $>\mathrm{T}$ locus is located near to the complementary sites of miR-3582, so the expression profiling of THRSP gene may be affected by such neighborhood. Then the adipose metabolism in tail could be regulated via alteration of transcription activities. This conclusion needs to be confirmed in the future studies.

The high levels of the THRSP expression patterns detected in the subcutaneous adipose and tail fat tissues in this study is consistent with expression data of THRSP gene in other mammals (Kuemmerle and Kinlaw, 2011). Compared with Altay sheep, Tan breed has much smaller fat tail size, produces more delicious meat and better lamb skin characteristics. These advantages make Tan sheep breed the most popular breed in Northern China. We were trying to compare mRNA abundance of THRSP in two sheep breeds for understanding the phenotypic and functional differences of fat deposition in sheep. In this research, THRSP mRNA levels in adipose were significantly higher than its level in liver in both breeds, while higher THRSP expression levels were observed among all three tissues in Tan sheep.

\section{CONCLUSION}

Gene variants affecting the phenotypic expression of fat-tailed trait in sheep are becoming a hot topic in molecular genetics. From our study, association between polymorphisms of THRSP gene and fat deposition was analyzed in fat-tailed and thin-tailed sheep breeds. THRSP gene expression profiles in adipose tissues between fattailed and thin-tailed breeds have also been evaluated. Our results might expand our understanding of THRSP gene regulating lipogenesis in fat-tailed sheep breed.

\section{ACKNOWLEDGEMENTS}

This work was supported by joint funds of the National Natural Science Foundation of China and the Government of Xinjiang Uygur Autonomous Region of China (No. U1130302), the Earmarked Fund for China Agriculture Research System (No. CARS-38), the Beijing Natural Science Foundation of China (No. 6144029), the Agricultural Science and Technology Innovation Program of China (No. ASTIP-IAS13), and the Special Fund for Basic Scientific Research of Institute of Animal Science, Chinese Academy of Agricultural Sciences (No. 2013ywfzd-1).

Statement of conflict of interest

The authors have indicated no conflicts of interest.

\section{REFERENCES}

Ahbara, A., Bahbahani, H., Almathen, F., Al Abri, M., Agoub, M.O., Abeba, A., Kebede, A., Musa, H.H., Mastrangelo, S., Pilla, F., Ciani, E., Hanotte, O. and Mwacharo, J.M., 2018. Genome-wide variation, candidate regions and genes associated with fat deposition and tail morphology in Ethiopian indigenous sheep. Front. Genet., 9: 699. https://doi. org/10.3389/fgene.2018.00699

Anderson, G.W., Zhu, Q., Metkowski, J., Stack, M.J., Gopinath, S. and Mariash, C.N., 2009. The THRSP null mouse $(T H R S P(\operatorname{tm} 1 \mathrm{cnm}))$ and diet-induced obesity. Mol. Cell. Endocrinol., 302: 99-107. https://doi.org/10.1016/j.mce.2009.01.005

Bai, J.L., Xu, H.W., Zang, R.X., He, H.J., Cai, Y., Cao, X., Peng, F.J., Han, J., Wu, J.P. and Yang, J.T., 2013. Cloning of the heart fatty acid-binding protein (H-FABP) gene and its tissue-specific expression profile in the Lanzhou fat-tailed sheep, Ovis aries. Small Rumin. Res., 112: 114-122. https://doi. org/10.1016/j.smallrumres.2012.12.016

Cao, Z.P., Wang, S.Z., Wang, Q.G., Wang, Y.X. and Li, H., 2007. Association of Spot14alpha gene polymorphisms with body weight in the chicken. Poult. Sci., 86: 1873-1880. https://doi.org/10.1093/ ps/86.9.1873

Chen, H.Q., Qin, J., Zhu, Y.J., Pan, Z.J., Xie, Y.N., Jiao, 
M.H., Chen, G.W., Chen, H. and Chu, M.X., 2012. The polymorphisms of goat THRSP gene associated with ecological factors in chinese indigenous goat breeds with different lipogenesis ability. Asian $J$. Anim. Vet. Adv., 7: 802-811. https://doi.org/10.3923/ ajava.2012.802.811

China National Commission of Animal Genetic Resources, 2011. Animal genetic resources in China: Sheep and goats. China Agriculture Press, Beijing.

Chou, W.Y., Cheng, Y.S., Ho, C.1., Liu, S.t., Liu, P.y., Kuo, C.C., Chang, H.P., Chen, Y.H., Chang, G.G. and Huang, S.M., 2007. Human spot 14 protein interacts physically and functionally with the thyroid receptor. Biochem. biophys. Res. Commun., 357: 133-138. https://doi.org/10.1016/j.bbrc.2007.03.103

Clop, A., Marcq, F., Takeda, H., Pirottin, D., Tordoir, X., Bibé, B., Bouix, J., Caiment, F., Elsen, J.M. and Eychenne, F., 2006. A mutation creating a potential illegitimate microRNA target site in the myostatin gene affects muscularity in sheep. Nature Genet., 38: 813-818. https://doi.org/10.1038/ng1810

Cornelius, P., MacDougald, O.A. and Lane, M.D., 1994. Regulation of adipocyte development. Ann. Rev. Nutri., 14: 99-129. https://doi.org/10.1146/annurev. nu.14.070194.000531

Donnelly, C., Olsen, A.M., Lewis, L.D., Eisenberg, B.L., Eastman, A. and Kinlaw, W.B., 2008. Conjugated linoleic acid (CLA) inhibits expression of the Spot 14 (THRSP) and fatty acid synthase genes and impairs the growth of human breast cancer and liposarcoma cells. Nutri. Cancer, 61: 114-122. https://doi.org/10.1080/01635580802348666

Farmer, S.R., 2006. Transcriptional control of adipocyte formation. Cell Metab., 4: 263-273. https://doi. org/10.1016/j.cmet.2006.07.001

Khaldari, M., Kashan, N., Afzalzadeh, A. and Salehi, A., 2008. Growth and carcass characteristics of crossbred progeny from lean-tailed and fat-tailed sheep breeds. S. Afri. J. Anim. Sci., 37: 51-56. https:// doi.org/10.4314/sajas.v37i1.4026

Kijas, J.W., Townley, D., Dalrymple, B.P., Heaton, M.P., Maddox, J.F., McGrath, A., Wilson, P., Ingersoll, R.G., McCulloch, R. and McWilliam, S., 2009. A genome wide survey of SNP variation reveals the genetic structure of sheep breeds. PLoS One, 4: e4668. https://doi.org/10.1371/journal. pone. 0004668

Kuemmerle, N.B. and Kinlaw, W.B., 2011. THRSP (thyroid hormone responsive). Atlas Genet. Cytogenet. Oncol. Haematol., 15: 480-482. https:// doi.org/10.4267/2042/45032

Lemor, A., Mielenz, M., Altmann, M., von Borell, E. and Sauerwein, H., 2010. mRNA abundance of adiponectin and its receptors, leptin and visfatin and of G-protein coupled receptor 41 in five different fat depots from sheep. J. Anim. Physiol. Anim. Nutri. (Berl) 94: e96-101. https://doi.org/10.1111/j.14390396.2010.00987.x

Mason, I.L., 1984. Evolution of domesticated animals. Longman, London, New York.

Mohammadi, H., Shahrebabak, M.M. and Sadeghi, M., 2013. Association between single nucleotide polymorphism in the ovine DGAT1 gene and carcass traits in two Iranian sheep breeds. Anim. Biotechnol., 24: 159-167. https://doi.org/10.1080/10495398.201 3.763816

Moisa, S.J., Shike, D.W., Faulkner, D.B., Meteer, W.T., Keisler, D. and Loor, J.J., 2014. Central role of the PPARgamma gene network in coordinating beef cattle intramuscular adipogenesis in response to weaning age and nutrition. Gene Regul. Syst. Biol., 8: $17-32$. https://doi.org/10.4137/GRSB.S11782

Moradi, M.H., Nejati-Javaremi, A., Moradi-Shahrbabak, M., Dodds, K.G. and McEwan, J.C., 2012. Genomic scan of selective sweeps in thin and fat tail sheep breeds for identifying of candidate regions associated with fat deposition. BMC Genet., 13: 10. https://doi. org/10.1186/1471-2156-13-10

Ortega, F.J., Vazquez-Martin, A., Moreno-Navarrete, J.M., Bassols, J., Rodriguez-Hermosa, J., Girones, J., Ricart, W., Peral, B., Tinahones, F.J., Fruhbeck, G., Menendez, J.A. and Fernandez-Real, J.M., 2010. Thyroid hormone responsive Spot 14 increases during differentiation of human adipocytes and its expression is down-regulated in obese subjects. Int. J. Obes., (Lond) 34: 487-499. https://doi. org/10.1038/ijo.2009.263

Pourlis, A.F., 2011. A review of morphological characteristics relating to the production and reproduction of fat-tailed sheep breeds. Trop. Anim. Hlth. Prod., 43: 1267-1287. https://doi.org/10.1007/ s11250-011-9853-x

Rosen, E.D. and MacDougald, O.A., 2006. Adipocyte differentiation from the inside out. Nature Rev. Mol. Cell Biol., 7: 885-896. https://doi.org/10.1038/ nrm2066

Rosen, E.D., Spiegelman, B.M., 2000. Molecular regulation of adipogenesis. Annul Rev. Cell Develop. Biol., 16: 145-171. https://doi.org/10.1146/annurev. cellbio.16.1.145

Sethupathy, P., Borel, C., Gagnebin, M., Grant, G.R., Deutsch, S., Elton, T.S., Hatzigeorgiou, A.G. and Antonarakis, S.E., 2007. Human microRNA-155 on chromosome 21 differentially interacts with its 
polymorphic target in the AGTR1 $3^{\prime}$ untranslated region: A mechanism for functional single-nucleotide polymorphisms related to phenotypes. Am. J. Human Genet., 81: 405-413. https://doi.org/10.1086/519979 Wang, X.L., Zhou, G.X., Xu, X.C., Geng, R.Q., Zhou, J.P., Yang, Y.X., Yang, Z.X. and Chen, Y.L., 2014. Transcriptome profile analysis of adipose tissues from fat and short-tailed sheep. Gene, 549: 252-257. https://doi.org/10.1016/j.gene.2014.07.072

Wang, Y.H., Bower, N.I., Reverter, A., Tan, S.H., De Jager, N., Wang, R., McWilliam, S.M., Cafe, L.M., Greenwood, P.L., Lehnert, S.A., 2009. Gene expression patterns during intramuscular fat development in cattle. J. Anim. Sci., 87: 119-130. https://doi.org/10.2527/jas.2008-1082

Wu, J., Wang, C., Li, S., Li, S., Wang, W., Li, J., Chi, Y., Yang, H., Kong, X. and Zhou, Y., 2013. Thyroid hormone-responsive SPOT 14 homolog promotes hepatic lipogenesis, and its expression is regulated by Liver $\mathrm{X}$ receptor $\alpha$ through a sterol regulatory element-binding protein 1c-dependent mechanism in mice. Hepatology, 58: 617-628. https://doi. org/10.1002/hep. 26272

Zeng, N., Huang, R., Li, N., Jiang, H., Li, R., Wang, F., Chen, W., Xia, M. and Wang, Q., 2018. MiR-451a attenuates free fatty acids-mediated hepatocyte steatosis by targeting the thyroid hormone responsive spot 14 gene. Mol. Cell. Endocrinol., 474: 260-271. https://doi.org/10.1016/j.mce.2018.03.016

Zhang, C.L., Zhao, Y.L., Wang, Y.H., Wu, H., Fang, X.T. and Chen, H., 2014. Deep RNA sequencing reveals that micrornas play a key role in lactation in rats. J. Nutri., 144: 1142-1149. https://doi.org/10.3945/ jn. 114.192575

Zhang, T., Gao, H., Sahana, G., Zan, Y., Fan, H., Liu, J., Shi, L., Wang, H., Du, L., Wang, L. and Zhao, F., 2019. Genome-wide association studies revealed candidate genes for tail fat deposition and body size in the Hulun Buir sheep. J. Anim. Breed. Genet., 136: 362-370. https://doi.org/10.1111/jbg.12402 